\title{
Evaluation of antioxidant and cytotoxic activity of extracts from fruits in fibroblastoma HT1080 cell lines: four fruits with commercial potential in Colombia
}

\author{
Luis Gonzalo Sequeda-Castañeda ${ }^{1,2 *}$, Andrés Roberto Barrera-Bugallo', Crispín Celis ${ }^{1}$, José Iglesias ${ }^{3}$, \\ Ludis Morales $^{3}$
}

${ }^{1}$ Departamento de Química, Facultad de Ciencias, Pontificia Universidad Javeriana, Bogotá, Colombia; ${ }^{2}$ Departamento de Farmacia, Facultad de Ciencias, Universidad Nacional de Colombia, Bogotá, Colombia; ${ }^{3}$ Departamento de Nutrición y Bioquímica, Facultad de Ciencias, Pontificia Universidad Javeriana, Bogotá, Colombia

\section{A B S T R A C T}

\begin{abstract}
Polyphenol compounds from plants have antioxidant activity because of their capacity of decrease the reactive oxidative species (ROS). Therefore, the search of new plant extracts containing polyphenols has been a priority of pharmaceuticals and research institutions. In this work we assessed the antioxidant activity and total phenol content in methanol extracts of four fruit with commercial potential in Colombia, such as Averrhoa carambola L., Bactris minor, Vaccinium meridionale and Vitis labrusca. In addition, we tested the effect of these fruit extracts on the reduction of viability induced by rotenone in cell lines HT1080. We report that Vaccinium meridionale exhibit a higher antioxidant capacity in comparison to others fruit extracts. However, all extracts present a slight antioxidant capacity in comparison to Vitamin C. Interestingly, all fruit extracts protect the HT1080 cells against reduction of viability induced by the rotenone, and Vitis labrusca present a best protection of these cells. Results describe some antioxidant properties of those fruits that could represent a therapy against disease generated by oxidative stress.
\end{abstract}

Keywords: Antioxidant capacity; Cytotoxic activity; Averrhoa carambola L., Star fruit; Carambolo; Bactris minor; Corozo; Vaccinium meridionale; Agraz; Vitis labrusca; Uva Isabella; HT1080 fibrosarcoma; Colombia

\section{INTRODUCTION}

Antioxidant properties of polyphenols are subject of ongoing research against illness related to oxidative stress-induced cell damage such as cancer, cardiovascular disease, Alzheimer Disease, Parkinson Disease and others neurodegenerative diseases (Valko et al., 2007; Circu and Aw, 2010; Albarracin et al., 2012; Sutachan et al., 2012). Polyphenols are characterized by the presence of multiple phenolic hydroxyl groups attached to ring structures, which classify them into different groups such as flavonoids, lignans and stilbenes. These structural rings act as reducing agents, hydrogen-donating antioxidants, metal chelators and singlet oxygen quenchers that give them the property of scavenger of reactive oxygen species (ROS). The beneficial role of polyphenol to the health is the reduction of ROS (Birt et al., 2001; Williams et al., 2004), which are compounds playing crucial roles in normal physiological processes including response to growth factors, the immune response, and apoptotic elimination of damaged cells (Seifried et al., 2007). However, defects of cell antioxidant machinery cause its accumulation harming seriously the cell (Valko et al., 2007).

ROS are oxygen-containing molecules that lose an electron and become extremely reactive. Cellular redox process generates hydrogen peroxides and superoxide radicals that according to its concentration could be beneficial for biological process such as immune response, or harmful for the stability of proteins, lipids and DNA of the cell (González et al., 2001). ROS accumulation causes oxidative stress that is the hallmark in several neurodegenerative and chronic diseases such as cancer, autoimmune disorders, cataracts, rheumatoid arthritis, ageing or cardiovascular disease (Ebrahimzadeh et al., 2010; Lopera et al., 2013). That is why it is necessary to develop antioxidant treatment

\footnotetext{
*Corresponding author:

Luis Gonzalo Sequeda-Castañeda, Departamento de Química, Facultad de Ciencias, Pontificia Universidad Javeriana, Bogotá, Colombia.

E-mail: Isequeda@javeriana.edu.co
}

Received: 19 November 2015;

Revised: 05 January 2016;

Accepted: 17 January 2016;

Published Online: 21 January 2016 
to decrease ROS by maintaining a balance between ROS and antioxidant level (González et al., 2001).

To combat the oxidative stress is available some compounds endogenously produced by cells, or exogenously obtained from nutrients or supplement with high level of antioxidants. These compounds scavenge the free radicals, inducing prevention and repair of the damages caused by ROS at cellular level. Hence, those compounds reduce and prevent the cancer and degenerative diseases (Kannan et al., 2010). Oxidative stress is a characteristic of cancer, which is a group diseases causing one in four death in United State of America (Siegel et al., 2014) and it is predicted to cause 15 millions of death by 2035 including 11 million from low- and middle-income countries such as those in Africa, Asia, Central and South America (Bender, 2014). Oxidative stress found in several types of cancer is the responsible of the DNA damage generating mutations in oncogenes or cancer suppressor genes. It has been identified more than 100 ROS-induced DNA damage that include DNA single or double strand break, purine, pyrimidine or deoxyribose modifications (Cooke et al., 2003; Cadet and Wagner, 2013). DNA damage leads to alteration of gene expression, signals transduction, DNA replication and genomic instability, and par consequent increase of carcinogenesis (Valko et al., 2007). It has been reported more than 150 epidemiological studies demonstrating antioxidant intake reduces the risk of several type of tumors; for instance, 170525 people supplemented with b-carotene decreases significantly risk of gastrointestinal cancer in comparison to placebo group (Rodríguez-Perón et al., 2001; Bjelakovic et al., 2004).

The utilization of synthetic antioxidant could reduce the ROS-induced damage in cell; however the possible toxicity and bad taste for consumers made tougher their utilization in comparison to natural antioxidant (Ebrahimzadeh et al., 2010). Therefore, it propels the investigation of plant source of antioxidants for health utilization; for instance, polyphenols (flavonoids, tannins, phenolic acids, etc) inside of vegetables, fruits or seeds are considered (Ebrahimzadeh et al., 2010).

In the present study it was evaluated the antioxidant and cytotoxic activity of extract from four fruit highly consumed in Colombia. The extracts from Averrboa carambola L. (carambolo), Vitis vinifera (Isabella grape), Bactris minor (corozo) and Vaccinium meridionale (agraz) are considered to exhibit a potential antioxidant and antitumoral properties because of its content of phenolic compounds (anthocyanins, flavanols, flavonols, etc, Table 1) (Gaviria Montoya et al., 2009; Tobar-Reyes et al., 2009; Abreu et al., 2014). However, so far there are no studies demonstrating a direct antioxidant and antitumoral capacity in cell lines culture.

\section{MATERIALS AND METHODS}

\section{Extract preparation}

The fruits were collected from plants cultured in several regions in Colombia. Vitis labrusca and Averrboa carambola were collected from the municipality of La Unión in Valle del Cauca. Bactris minor was collected from the municipality of Montería in Córdoba. And finally, Vaccinium meridionale was collected from the municipality of San Miguel in Boyacá.

The extracts were prepared by using maceration technique (Raaman, 2006). Briefly, 100 grams of each grinded fruit (epicarp and mesocarp, the seeds were excluded) were incubated in $500 \mathrm{ml}$ of $\mathrm{HCl} 1 \mathrm{~N}$-acidified methanol during eight days. Then, methanol extracts were evaporated in rotavap to obtain fluid extract, which it was lyophilized for 48 hours.

\section{Assessment of antioxidant capacity by DPPH and ABTS DPPH method}

Antioxidant activity of the extracts was assessed by 2,2-diphenyl-1-picryl-hydrazyl-hydrate (DPPH) free radical assay. This violet reactive has antioxidant activity by trapping radicals and turning to transparent color. The reaction was performed by adding $975 \mu \mathrm{l}$ of $1 \mathrm{mg} / \mathrm{ml} \mathrm{DPPH}$ diluted in methanol, and $25 \mu \mathrm{l}$ of each extract diluted in deionized water at different working concentrations of 50,500,1000, 2000 , and $4000 \mathrm{ppm}$ that were previously prepared from $5000 \mathrm{ppm}$ stock solution diluted in deionized water. $1 \mathrm{ml}$ of reactions with different concentrations of extracts (1.25, $12.5,25,50$ and $100 \mathrm{ppm})$ was incubated for 30 minutes at room temperature, and the decreasing absorbance was recorded at $516 \mathrm{~nm}$. The percentage of inhibition (turning violet to transparent color) was determined by using the $\mathrm{I}=[(\mathrm{Ao}-\mathrm{Ae}) / \mathrm{Ao}] \mathrm{x} 100$ equation, where Ao is absorbance without extract, and Ae is the absorbance with extracts. To get $\mathrm{IC}_{50}$ of extracts turning to transparent color that indicate antioxidant capacity, was calculated by plotting $\%$ of inhibition vs. extract concentration; then linear regression equation was calculated $(y=m x+b)$, and $50 \%$ inhibitory concentration by the equation $\mathrm{IC}_{50}=(50-\mathrm{b}) / \mathrm{m}$. The results were compared to those obtained using Trolox and Vitamin C (Brand-Williams et al., 1995; Tyrakowska et al., 1999; Kuskoski et al., 2005; Sequeda-Castañeda, 2008).

\section{ABTS method}

The 2,2'-azino-bis(3-ethylbenzothiazoline-6-sulphonic acid) (ABTS) is chemical that becomes a radical cation after oxidation by potassium persulfate having absorbance at $734 \mathrm{~nm}$. This blue ABTS radical cation turns to colorless solution in presence of antioxidants such as vitamin C. Hence, the capacity of clearing ABTS oxidized solution by 
Table 1: Polyphenols compounds present in Averrhoa carambola, Bactris minor, Vaccinium meridionale and Vitis labrusca

\begin{tabular}{|c|c|c|c|c|}
\hline Fruit & Metabolite & Quantity & Method & Reference \\
\hline \multirow[t]{2}{*}{$\begin{array}{l}\text { Averrhoa } \\
\text { carambola }\end{array}$} & \multirow[t]{2}{*}{ Flavonoids } & $\begin{array}{l}67 \text { mg per gram } \\
\text { dry weight }\end{array}$ & $\begin{array}{l}\text { HPLC-DAD. } \\
\text { UV-Vis }\end{array}$ & Yan et al., 2013 \\
\hline & & $\begin{array}{l}42.7 \text { mg per gram } \\
\text { dry weight }\end{array}$ & $\begin{array}{l}\text { HPLC-DAD. } \\
\text { UV-Vis }\end{array}$ & Khanam et al., 2015 \\
\hline \multirow[t]{2}{*}{ Bactris minor } & $\begin{array}{l}\text { Anthocyanins: cyanidin-3-rutinoside, } \\
\text { cyanidin-3-glucoside, peonidin-3-rutinoside, } \\
\text { peonidin-3-glucoside, cyanidin-3-(6-O-malonyl) } \\
\text { glucoside, cyanidin-3-sambubioside }\end{array}$ & $\begin{array}{l}1.5 \mathrm{mg} \text { per gram } \\
\text { fresh weight }\end{array}$ & $\begin{array}{l}\text { HSCCC. } \\
\text { HPLC-ESI/MS-MS. } \\
\text { UV-Vis }\end{array}$ & Osorio et al., 2010 \\
\hline & $\begin{array}{l}\text { Anthocyanins: cyanidin 3-rutinoside, cyanidin } \\
\text { 3-O-glucoside }\end{array}$ & $147 \mathrm{mg} / \mathrm{L}$ & $\begin{array}{l}\text { HPLC-DAD. } \\
\text { UV-Vis }\end{array}$ & Rojano et al., 2012 \\
\hline \multirow[t]{3}{*}{$\begin{array}{l}\text { Vaccinium } \\
\text { meridionale }\end{array}$} & \multirow{3}{*}{$\begin{array}{l}\text { Anthocyanins: cyanidin 3-galactoside, } \\
\text { cyanidin 3-glucoside, cyanidin 3-arabinoside, } \\
\text { delphinidin-3-O-glucoside }\end{array}$} & $\begin{array}{l}201 \mathrm{mg} \text { per } 100 \mathrm{~g} \\
\text { fresh weight }\end{array}$ & UV-Vis & Gaviria Montoya et al., 2009 \\
\hline & & $\begin{array}{l}329 \mathrm{mg} \text { per } 100 \mathrm{~g} \\
\text { fresh weight }\end{array}$ & $\begin{array}{l}\text { HPLC-DAD. } \\
\text { HPLC-ESI/MS-MS }\end{array}$ & Garzón et al., 2010 \\
\hline & & $\begin{array}{l}151 \mathrm{mg} \text { per } 100 \mathrm{~g} \\
\text { fresh weight }\end{array}$ & UV-Vis & Maldonado-Celis et al., 2014 \\
\hline \multirow[t]{5}{*}{ Vitis labrusca } & Flavonols: myricetin, kaempferol, quercetin & $\begin{array}{l}296 \mathrm{mg} \text { per } 100 \mathrm{~g} \\
\text { fresh weight }\end{array}$ & \multirow[t]{2}{*}{ HPLC-DAD } & \multirow[t]{2}{*}{ Burin et al., 2014} \\
\hline & Flavanols: (+)-catechin, (-)-epicatechin & $\begin{array}{l}440 \mathrm{mg} \text { per } 100 \mathrm{~g} \\
\text { fresh weight }\end{array}$ & & \\
\hline & $\begin{array}{l}\text { Anthocyanins: cyanidin-3,5-diglucoside, } \\
\text { cyanidin-3-O-glucoside, malvidin-3,5-diglucoside, } \\
\text { malvidin-3-O-glucoside, peonidin-3-O-glucoside, } \\
\text { delphinidin-3-O-glucoside }\end{array}$ & $1592 \mathrm{mg} / \mathrm{L}$ & \multirow[t]{3}{*}{$\begin{array}{l}\text { HPLC-Vis. } \\
\text { UV-Vis }\end{array}$} & \multirow[t]{3}{*}{ Toaldo et al., 2015} \\
\hline & Flavonols: myricetin, kaempferol, quercetin & $15 \mathrm{mg} / \mathrm{L}$ & & \\
\hline & Flavanols: (+)-catechin, (-)-epicatechin & $554 \mathrm{mg} / \mathrm{L}$ & & \\
\hline
\end{tabular}

many compounds is considered as its antioxidant capacities. It was prepared an ABTS solution $(1 \mathrm{mg} / \mathrm{ml} \mathrm{ABTS}$ and $890 \mu \mathrm{M}$ potassium persulfate) that was incubated at room temperature for 16 hours. The conditions for assessing the antioxidant capacity of the fruit extracts were the same of DPPH assay (Re et al., 1999; Tyrakowska et al., 1999; Kuskoski et al., 2005; Sequeda-Castañeda, 2008).

\section{Phenol content measurement}

Total phenol content was measurement by using the FolinCiocalteu reagent (FCR). Briefly, $2 \mathrm{mg}$ of the different lyophilized extracts were diluted in $50 \mathrm{ml}$ of distilled water, of which an aliquot of $0.5 \mathrm{ml}$ is incubated with $0.75 \mathrm{ml}$ of FCR for 5 minutes at room temperature (RT). Then, $0.75 \mathrm{ml}$ of $20 \%$ sodium carbonate solution was added to the mixture to get a final volume of $2 \mathrm{ml}$ that is mixed briefly, and incubated at RT for 90 minutes. The reducing capacity of phenols reacts with the FCR, and the mixture turn to blueish color with the absorbance recorded at 760 nm (Singleton et al., 1999; Kuskoski et al., 2005; Sequeda-Castañeda, 2008). To determine the exact amount of phenols in the extracts, gallic acid standard curve was performed. For this purpose, $0.1 \mathrm{~g} / \mathrm{L}$ gallic acid stock solution was ten-fold diluted in water. Then, different aliquots of 20,40,60, 80 and $100 \mu \mathrm{l}$ of these dilutions were mixed with $250 \mu \mathrm{l}$ of FCR, and incubated for 5 minutes, and then $250 \mu \mathrm{l} 20 \%$ sodium carbonate solution was added to each aliquots that were brought them up to $2 \mathrm{ml}$ with distilled water, finally these solutions were incubated for
90 minutes at RT. The content of total phenol in the extract is represent as gallic acid in 100 grams of fruit.

\section{Effect of extracts on cell line viability}

The dose-response effect of Isabella grape, corozo, carambolo and agraz extracts on HT1080 cell line viability was performed by using MT'T assay. This method described by Mosmann and modified by Ahmadian, assess the mitochondrial function because of the isocitrate dehydrogenase, in the inner mitochondrial membrane at respiratory chain, reduces the MT'T (3-[4,5-dimethylthiazol2-yl]-2,5-diphenyltetrazolium bromide) into the blue formazan product, which is recorded by spectrophotometry at $595 \mathrm{~nm}$ (Mosmann, 1983; Ahmadian et al., 2009). Briefly, 4000 cells/well were seeded in 96-wells plate and exposed to different concentrations of extracts $(10,50$ y $100 \mu \mathrm{g} / \mathrm{ml})$ for 24 hours. Then, culture medium was taken out from each well, and replaced by new media without phenol red (salt's Earle [EBS] 2X supplemented with glucose), and with $10 \mu \mathrm{l}$ of $5 \mathrm{mg} / \mathrm{ml}$ MTT solution prepared in PBS $1 \mathrm{X}$, and then the cells were incubated at $5 \% \mathrm{CO}_{2}$ and $37^{\circ} \mathrm{C}$ for 4 hours. After incubation time completed, the media was replaced with $100 \mu \mathrm{l}$ of DMSO, and incubated for 10 minutes under shaking in order to dissolve the formazan crystals. After the color was homogenized, the absorbance of each well was recorded at $595 \mathrm{~nm}$. Higher absorbances (Abs) represent higher mitochondrial function, so that the cell viability is enhanced. Percentage of viability was calculated by the equation: $\%$ of viability $=$ Abs of cells 
treated x 100/Abs of cells untreated.

\section{Assessment of antioxidant activity of extract on cell lines}

Oxidative stress was induced in HT1080 cell line by using rotenone, which is an oxidant agent because of its inhibition the capacity of complex I at electron transport chain in the inner mitochondrial membrane generating superoxide and peroxide accumulation in the cell. For this purpose 4000 cells/well were seeded in 96-wells plate in media. 24 hours after adhesion, three groups of cells were treated with 10,50 or $100 \mu \mathrm{g} / \mathrm{ml}$ of different extracts for 48 hours, and then each group of cells were treated with $1 \mu \mathrm{M}$ of rotenone for 24 hours. Finally, the cell viability was assessed by using MTT as described above (Matsuda et al., 2006; Matsuda et al., 2007).

\section{Statistical analysis}

The sofware GraphPad Prism version 5 was used. All experiments were done in tetraplicate $(\mathrm{n}=4)$ and results were expressed as means \pm standard deviations. Analysis of variance was analysed using the Tukey HSD test based on significant difference of $\mathrm{p}<0.05$.

\section{RESULTS AND DISCUSSION}

\section{Antioxidant capacity and total phenol content}

In order to assess antioxidant capacities of the methanol extracts of fruits, it was performed DPPH and ABTS assays as described above. In these assays an extract-induced decrease of absorbance, the solution becomes colorless, suggests that the extracts exhibit higher antioxidant capacities. $\mathrm{IC}_{50}$ of the extracts in the absorbance decrease were compared to those of the Trolox and Vitamin C that are considered as positive controls. In Table 2, it is indicated that Vaccinium meridionale extract exhibits the higher antioxidant capacity, the IC50's are $3.8 \pm 0.3$ and $22.9 \pm 5.4 \mathrm{ppm}$ in ABTS and DPPH assays, respectively. It is followed by Vitis labrusca extract showing $14.4 \pm 1.1 \mathrm{y}$ $29.1 \pm 1.7 \mathrm{ppm}$ in ABTS and DPPH assays, respectively. The higher total phenol content in Vaccinium meridionale extract, $86 \pm 4 \mathrm{mg}$ gallic acid/100 $\mathrm{mg}$ of sample, is in agreement with its enhanced antioxidant capacity, probably due to its high content of anthocyanins and others phenols (Gaviria Montoya et al., 2009; Garzón et al., 2010). In addition, it is well known the good performance of methanol (Paladino, 2008; Borges et al., 2011) and solvents such as ethanol, ethyl acetate and acetone in the isolation of high antioxidant compounds such as flavonoids, isoflavones, catechins and proanthocyanidins (Birt et al., 2001; Arranz-Martínez, 2010). The extracts of Bactris minor, Vitis labrusca and Averrboa carambola, with less antioxidant capacities exhibited less total phenol content $78 \pm 4,49 \pm 3$ and $46 \pm 2 \mathrm{mg}$ gallic acid/100 $\mathrm{mg}$ of sample, respectively.
Table 2: Antioxidant capacities and total phenol content in methanol extract of fruits

\begin{tabular}{lcccc}
\hline Fruit extract & \multicolumn{2}{c}{ IC $_{50}$ (ppm) } & & Total phenols \\
\cline { 2 - 3 } \cline { 5 - 5 } & ABTS & DPPH & & mg GA*100 g $^{*}$ \\
\hline Vitis labrusca & $14.4 \pm 1.1$ & $29.1 \pm 1.7$ & & $49 \pm 3$ \\
Averrhoa carambola & $42.7 \pm 0.7$ & $58.5 \pm 3.1$ & & $46 \pm 2$ \\
Bactris minor & $29.4 \pm 1.6$ & $97.4 \pm 3.6$ & & $78 \pm 4$ \\
Vaccinium meridionale & $3.8 \pm 0.3$ & $22.9 \pm 5.4$ & $86 \pm 4$ \\
Trolox & $3.1 \pm 0.1$ & $4.2 \pm 0.5$ & --- \\
Vitamina C & $2.1 \pm 0.1$ & $3.1 \pm 0.1$ & --- \\
\hline
\end{tabular}

${ }^{*}$ Gallic acid

Furthermore, dark colors such as red and purple of the fruits as Vaccinium meridionale and Vitis labrusca showed highest total phenol content and antioxidant capacities, and in same way the pale fruit such as Averrhoa carambola has less antioxidant capacity (Table 2). Formerly, it has been related the dark colors of fruits with its antioxidant capacities (García-Alonso et al., 2004).

\section{Cytotoxic activity of the extracts in HT1080 cell lines}

To analyze whether the extracts present cytotoxic activity in HT1080 cell lines, we tested the effect of $10 \mu \mathrm{g} / \mathrm{ml}$, $50 \mu \mathrm{g} / \mathrm{ml}$ and $100 \mu \mathrm{g} / \mathrm{ml}$ of extracts on cell viability. These concentrations were chosen based on the experiments performed by Matsuda et. al. 2006, where it was performed a dose response between 0 and $100 \mu \mathrm{g} / \mathrm{ml}$ of methanol extracts, and in the experiments from Sonoda et. al. 2004 where it was defined a cytotoxic concentration of HT1080 cells to methanol extracts between $3.8 \mu \mathrm{g} / \mathrm{ml}$ to $50 \mu \mathrm{g} / \mathrm{ml}$ (Sonoda et al., 2004; Matsuda et al., 2006; Matsuda et al., 2007). Number were seeded in plate, and incubated in media at a $37^{\circ} \mathrm{C}, 10 \%$ humidity, and in atmosphere of $5 \% \mathrm{CO}_{2}$ for 24 hours to allow the adhesion. After adhesion the cells were treated with the extracts for 48 hours, and cell viability was recorded by using MTT assay according to the protocol provider by the supplier.

The absorbance values obtained in the MTT assay, which indicate an intracellular reducing environment, are presented as percentage of viability of the extracts-treated HT1080 cells divided by non-treated cells. The assays were repeated three times by using four wells each time $(n=4)$. The Figure 1 illustrates the percentage of viability of the HT1080 cell line to four extracts (A is V. labrusca, B is B. minor, $\mathrm{C}$ is $A$. carambola, $\mathrm{D}$ is $V$. meridionale). We found no toxicity in any concentration of extract assessed. The percentage of viability of each concentration of extract were no significant in comparison to control $(\mathrm{P}>0,05)$. Tukey's test was used to calculate the significance values by using the absorbance of MTT assay. Hence, we conclude that any extract reduce the viability of HT1080 cell lines in the assessed concentrations.

The absence of cytotoxic activity on the fruit extracts could 


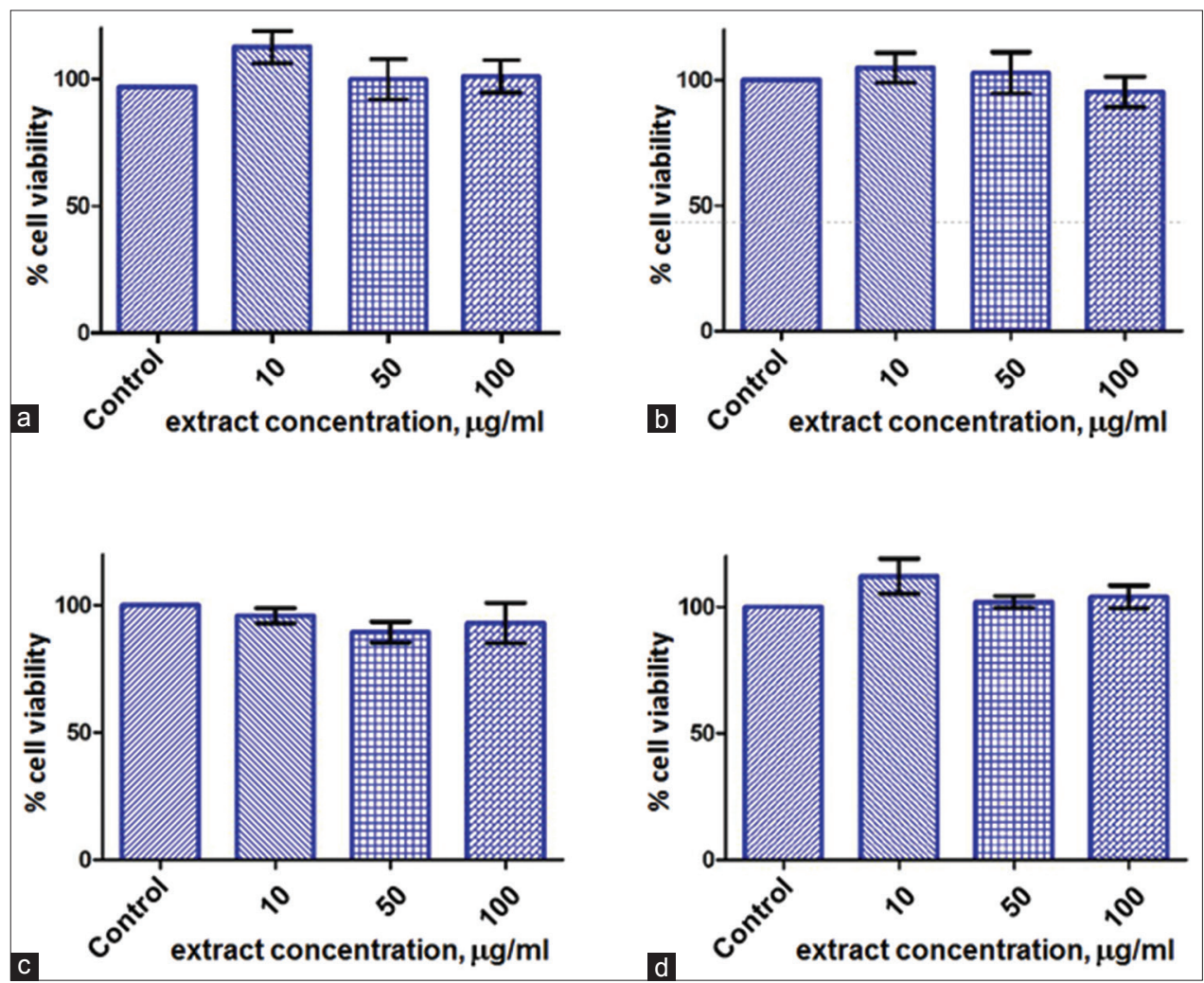

Fig 1. Cytotoxicity activity of fruit extract in HT1080 cell lines. Percentage of viability of the cells to different concentrations of the extracts. A: Vitis labrusca. B: Bactris minor. C: Averrhoa carambola. D: Vaccinium meridionale. Three different experiment with four replicates (wells) each one $(n=4)$. Significance values $(P>0.05)$ was calculated with Tukey's test by using the absorbance of MTT assay

be explained by the complete lack or low concentrations of cytotoxic compounds to HT1080 cells. However, it is necessary to screen higher concentrations of the extracts, and to study the fragmentation pattern of the extracts in order to test the effect of polyphenol enriched fractions of different polarities on cell viability.

\section{Effect of the extracts against reactive species oxygen}

The antioxidant activity found in the extract propels us to evaluate a possible protective effect of the extracts against reactive species oxygen (ROS) generated in the cells. To generate ROS at cellular level we treated HT1080 cell lines with a well-known natural pesticide, rotenone, which is an isoflavone occurring in the roots of several tropical plants, such as Derris and Lonchocarpus (Haller et al., 1942). Lipophilic property of rotenone allows entry into the cell without any receptor; and once there, it interferes with mitochondrial electron chain by inhibiting the electron transfer from NADH dehydrogenase to ubiquinone, and for consequence produced superoxide and peroxide radicals generate oxidative stress. Final consequence of that is the activation of apoptosis-dependent caspase- 3 (Li et al., 2003).

First we assessed the effect of different rotenone concentrations on cellular morphology. We set a dose response of rotenone to the cell culture morphology; for that, we seeded 4000 HT1080 cells in the well of 96-wells plate, and incubate them for 24 hours until complete adhesion. Next the cells were treated with $100 \mathrm{nM}, 500 \mathrm{nM}$, $1 \mu \mathrm{M}, 5 \mu \mathrm{M}$ or $10 \mu \mathrm{M}$ of rotenone for 48 hours. Light microscopy images evidence the normal HT1080 cell culture characteristics in non-treated control, such as ovoid shape with small nucleus, clear cytoplasm surrounded with hyaline collagenous fibers and lateral protrusions (Fig. 2a). In addition, these cells growth in many layers forming mini tumors in the plate (Fig. 2a) (Rasheed et al., 1974).

In the treated cells appeared morphological signs of apoptosis, such as cytoplasmic condensations, granules formation and cellular fragments (Fig. 2b-f). These signs appeared progressively and show that 100 and $500 \mathrm{nM}$ rotenone treated culture still presents high density, microtumors and lateral protrusions but the abundant vacuoles are already formed suggesting apoptosis (Fig. 2bc). In the same way, in the $1 \mu \mathrm{M}, 5 \mu \mathrm{M}$ or $10 \mu \mathrm{M}$ rotenone treated cell culture is possible observe a decreasing cell density, less micro tumors appearance, higher amount of vacuoles, and increasing number of residual cell bodies suggesting a rotenone-induced apoptosis.

To set the rotenone concentration causing more than $60 \%$ 


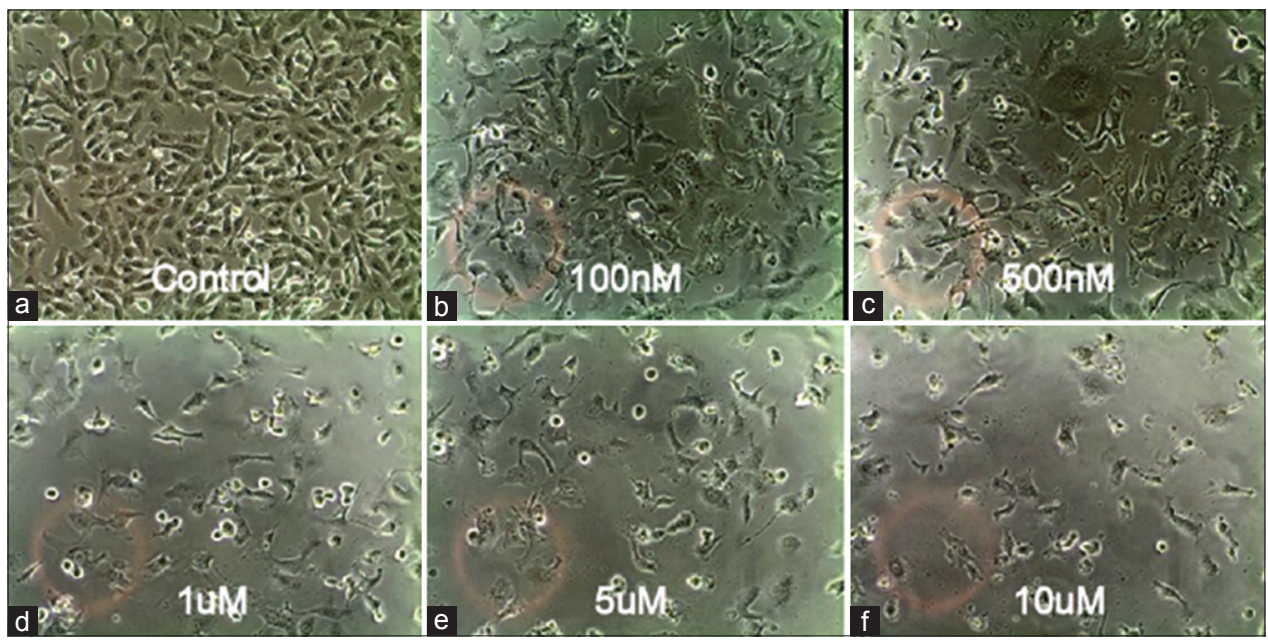

Fig 2. Effect of different concentration of rotenone on HT1080 cell culture morphology. Normal morphology in non-treated cells (a). Decreasing cell number and increasing vacuoles amount in treated cells $(b-f)$.

of cell viability decrease, we perform a rotenone dose response in MTT recorded cell viability as described in materials and methods. $0.1 \mu \mathrm{M}, 0.5 \mu \mathrm{M}, 1 \mu \mathrm{M}, 5 \mu \mathrm{M}$ and $10 \mu \mathrm{M}$ of rotenone generates a percentage of cell viability of $58 \pm 3,48 \pm 3,39 \pm 1,30 \pm 2$ y $9 \pm 1 \%$, respectively. We set $1 \mu \mathrm{M}$ of rotenone to get less than $40 \%$ of cell viability for extracts test.

Once rotenone concentration has been established, we assessed the effect of different concentrations of extracts on the decrease in cell viability induced by rotenone. For that, we seeded HT1080 400 cells in a well of 96-well plate, and incubate them for 24 hours until complete adhesion. Next, the cells were treated with 10,50 or $100 \mu \mathrm{g} / \mathrm{ml}$ of each extract for 48 hours; after that the cells were treated with $1 \mu \mathrm{M}$ of rotenone for 48 hours before the MTT cell viability test was done.

The Figure 3 illustrates a protective effect of fruit extracts on the decrease of cell viability induced by $1 \mu \mathrm{M}$ of rotenone. It was performed three independent experiment with 4 replicates (wells) each one $(n=4)$. The data are presented as percentage of HT1080 cell viability, which is calculated dividing the MTT absorbance of extract treated cells between MTT absorbance of non-treated cells. 10 $\mu \mathrm{g} / \mathrm{ml}$ of Vitis labrusca extracts did not show significative (n.s. $\mathrm{P}>0.05$ ) protection of cell viability against harmful effect of rotenone, by the contrast 50 and $100 \mu \mathrm{g} / \mathrm{ml}$ of these extracts increased respectively the cell viability 1,5 and 2 fold versus rotenone control cells, with a $\mathrm{P}$ value less than 0.001 (Figure 3A). In the case of Bactris minor extracts, only $100 \mu \mathrm{g} / \mathrm{ml}$ treatment exhibits a significant $(* * * \mathrm{P}<0.001)$ protection against diminution of cell viability induced by rotenone, neither $10 \mu \mathrm{g} / \mathrm{ml}$ nor $50 \mu \mathrm{g} /$ $\mathrm{ml}$ extract treatment present any significant protection (Fig. 3B). Averrho a carambola extracts presenting significant
$(* * \mathrm{P}<0.01)$ protection are the treatment of $50 \mathrm{mg} / \mathrm{ml}$ of extracts (Fig. 3C). Surprisingly the $10 \mu \mathrm{g} / \mathrm{ml}$ and $10010 \mu \mathrm{g} /$ $\mathrm{ml}$ extract concentration did not present any protection to rotenone. As the results of Vitis labrusca above, the extracts of Vaccinium meridionale present a significant protection in cell viability against rotenone at the concentration of 50 and $100 \mu \mathrm{g} / \mathrm{ml}(* * \mathrm{P}<0,01 ; * * * \mathrm{P}<0,001$, respectively), however it is lower than that of Vitis labrusca (Fig. 3D). The concentration of $10 \mu \mathrm{g} / \mathrm{ml}$ did not show any significant protection, as well as each extract assessed in in this experiment.

In the Fig. 3 is evidenced the antioxidant protection of some concentrations of the fruit extracts. Interestingly, this protection occurs against rotenone that is a strong inhibitor of complex 1 of mitochondrial electron chain. The effect of rotenone is the production of abundant free radical leading and oxidative stress to apoptosis ( $\mathrm{Li}$ et al., 2003). The extracts of fruits increase the HT1080 cell viability when the cell are treated with 50 or $100 \mu \mathrm{g} / \mathrm{ml}$ of extract for 48 hours before the oxidative stress induced by rotenone. As it is reported above, the fruit extracts does not induce viability in healthy cells (Fig. 1), it is possible to argue that the fruit extract contain high level of antioxidants inducing protection against the rotenone-induced oxidative stress. We report that the stronger antioxidant activity of the fruit extracts assessed belong to Vitis labrusca, it had $30 \pm 3 \%$ of protection against the injury induced by rotenone, it is follow Bactris minor, Vaccinium meridionale and Averrhoa carambola extracts with $26 \pm 10 \%, 19 \pm 2 \%$ and $10 \pm 1 \%$ of protection, respectively. All of these percentages of protection were reached at extract concentration of $500 \mu \mathrm{g} / \mathrm{ml}$, except for Averrhoa carambola extract that presented its better protection at $100 \mu \mathrm{g} / \mathrm{ml}$.

It is well known that phenol inhibits the harmful effect 


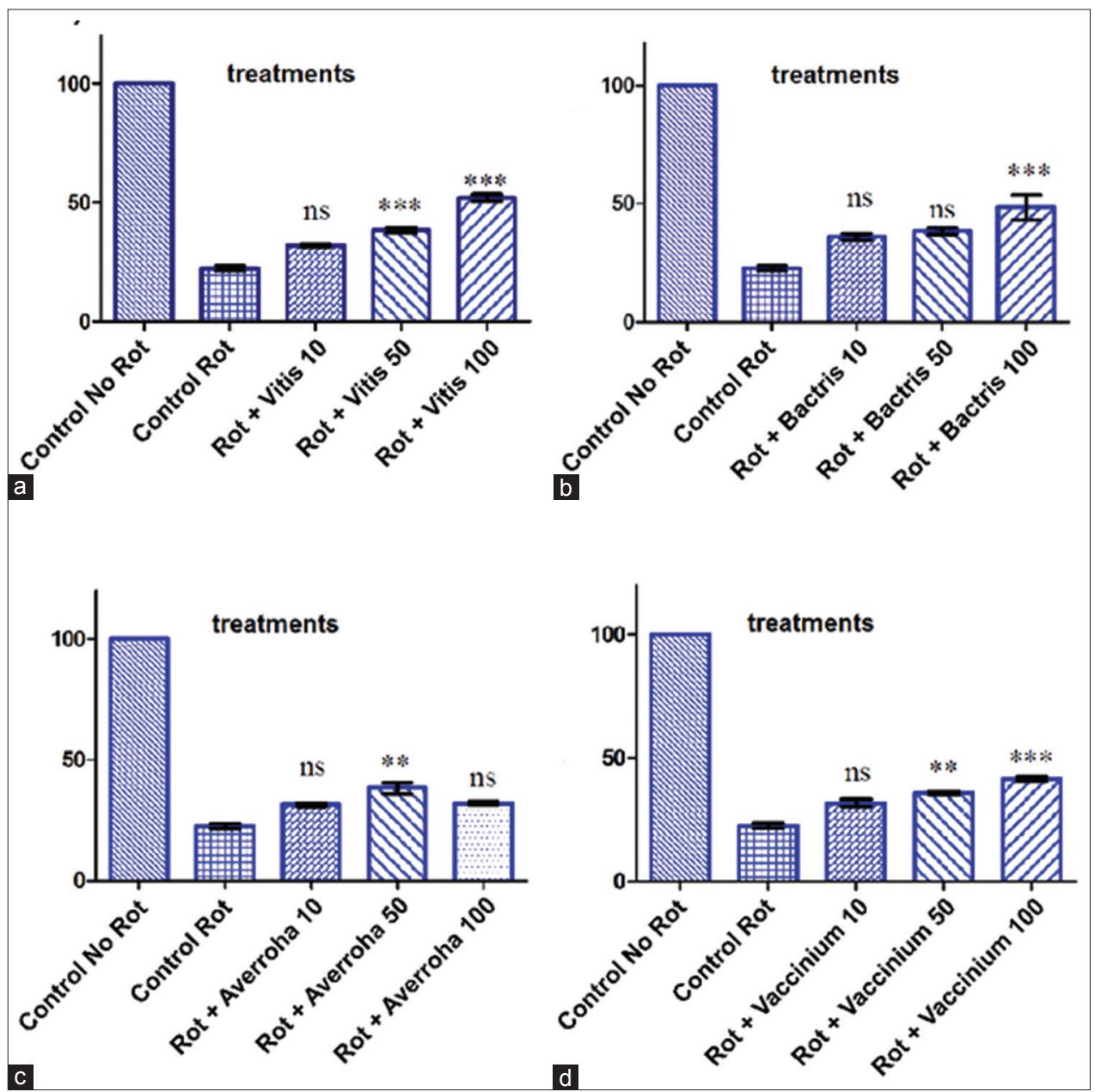

Fig 3. Effect of fruit extracts on the decrease in the HT1080 cell viability induced by the rotenone. Effect of the $10,50 \mathrm{and} 100 \mathrm{\mu g} / \mathrm{ml}$ of fruit extracts on HT1080 cell viability impaired with $1 \mu \mathrm{M}$ of rotenone. A: Vitis labrusca. B: Bactris minor. C: Averrhoa carambola. D: Vaccinium meridionale. Three independent experiments with 4 replicates each one $(n=4)$. Significance values was calculated with Tukey's test by using the absorbance of MTT assay; ${ }^{* *} \mathrm{P}<0.01,{ }^{* *} \mathrm{P}<0.001, \mathrm{~ns}=$ non-significant.

of oxidative stress (Martínez-Flórez et al., 2002), because of flavones and isoflavones transfer electron to free radicals, and it remove oxidative chain generating by these radicals. The antioxidant molecule does not became a new antioxidant because of the restante electron in antioxidant molecule is inactive. At cellular level occurs because of superoxide anion, singlet oxygen molecular and peroxide radicals are neutralized by antioxidant extracts.

\section{CONCLUSION}

Vitis labrusca showed the higher antioxidant capacity in DPPH and ABTS tests. In this report we evidence a direct correlation between total phenol content and antioxidant capacity tested by DPPH and ABTS assays. In addition, the fruits extracts did not show cytotoxic activity in healthy HT1080 cell lines. These antioxidant capacities of the fruit extracts protect HT1080 cell lines against an oxidative stress generated by the rotenone. Taking all together we can propose these fruits extract as therapeutic strategies for numerous disease related to oxidative stress injuries, as neurodegenerative disease, cancer and diabetes type II.

\section{ACKNOWLEDGMENTS}

This work was funded by the Academic Vice-Rectory and Vice-Rectory for Research of the Pontificia Universidad Javeriana (project 4033). The authors acknowledge the collaboration and support of the Professors Jhon Jairo Sutachán and Sonia Luz Albarracín of the Pontificia Universidad Javeriana (PUJ).

\section{Author contributions}

ARBB made sample preparation, biological activities, discussion and conclusion in their theses. CC, JI and LM was involved in the methodology and manuscript writing. LGSC made a major contribution to the paper, was involved in overall planning, supervision, manuscript 
writing, is the lead scientist and corresponding author.

\section{REFERENCES}

Abreu, O. A., G. Barreto and S. Prieto. 2014. Vaccinium (Ericaceae): Ethnobotany and pharmacological potential. Emirates J. Food Agric. 26(7): 577-591.

Ahmadian, S., J. Barar, A. A. Saei, M. A. Fakhree and Y. Omidi. 2009. Cellular toxicity of nanogenomedicine in MCF-7 cell line: MTT assay. J. Vis. Exp. (26): e1191.

Albarracin, S. L., B. Stab, Z. Casas, J. J. Sutachan, I. Samudio, J. Gonzalez, F. Capani, L. Morales and G. E. Barreto. 2012. Effects of natural antioxidants in neurodegenerative disease. Nutr. Neurosci. 15(1): 1-9.

Arranz-Martínez, S. 2010. Compuestos polifenólicos (extraíbles y no extraíbles) en alimentos de la dieta española: Metodología para su determinación e identificación. [PhD Dissertation]. Madrid, España: Universidad Complutense de Madrid.

Bender, E. 2014. Developing world: Global warning. Nature. 509(7502): S64-S65.

Birt, D. F., S. Hendrich and W. Wang. 2001. Dietary agents in cancer prevention: Flavonoids and isoflavonoids. Pharmacol. Ther. 90(2-3): 157-177.

Bjelakovic, G., D. Nikolova, R. G. Simonetti and C. Gluud. 2004. Antioxidant supplements for prevention of gastrointestinal cancers: A systematic review and meta-analysis. Lancet. 364(9441): 1219-1228.

Borges, G. D. S. C., F. G. K. Vieira, C. Copetti, L. V. Gonzaga and R. Fett. 2011. Optimization of the extraction of flavanols and anthocyanins from the fruit pulp of Euterpe edulis using the response surface methodology. Food Res. Int. 44(3): 708-715.

Brand-Williams, W., M. E. Cuvelier and C. Berset. 1995. Use of a free radical method to evaluate antioxidant activity. Food Sci. Technol-LEB. 28(1): 25-30.

Burin, V. M., N. E. Ferreira-Lima, C. P. Panceri and M. T. BordignonLuiz. 2014. Bioactive compounds and antioxidant activity of Vitis vinifera and Vitis labrusca grapes: Evaluation of different extraction methods. Microchem. J. 114: 155-163.

Cadet, J. and J. R. Wagner. 2013. DNA base damage by reactive oxygen species, oxidizing agents, and UV radiation. Cold Spring Harb. Perspect. Biol. 5(2): 1-18.

Circu, M. L. and T. Y. Aw. 2010. Reactive oxygen species, cellular redox systems, and apoptosis. Free Radic. Biol. Med. 48(6): 749-762.

Cooke, M. S., M. D. Evans, M. Dizdaroglu and J. Lunec. 2003. Oxidative DNA damage: Mechanisms, mutation, and disease. FASEB J. 17(10): 1195-1214.

Ebrahimzadeh, M., S. Nabavi, S. Nabavi, F. Bahramian and A. Bekhradnia. 2010. Antioxidant and free radical scavenging activity of $H$. officinalis L. var. angustifolius, $V$. odorata, B. hyrcana and C. speciosum. Pak. J. Pharm. Sci. 23(1): 29-34.

García-Alonso, M., S. De Pascual-Teresa, C. Santos-Buelga and J. C. Rivas-Gonzalo. 2004. Evaluation of the antioxidant properties of fruits. Food Chem. 84(1): 13-18.

Garzón, G. A., C. E. Narváez, K. M. Riedl and S. J. Schwartz. 2010. Chemical composition, anthocyanins, non-anthocyanin phenolics and antioxidant activity of wild bilberry (Vaccinium meridionale Swartz) from Colombia. Food Chem. 122(4): 980-986.

Gaviria M. C., C. O. Ospina, N. S. Mesa, C. M. Cano, M. L. Arias, P. G. García, et al. 2009. Actividad antioxidante e inhibición de la peroxidación lipídica de extractos de frutos de mortiño (Vaccinium meridionale SW). Bol. Latinoam Caribe Plant Med. Aromat. 8(6): 519-528.

González, M. L., P. Muñiz-Rodríguez and V. Valls-Bellés. 2001. Actividad antioxidante de la cerveza: Estudios in vitro e in vivo. Rev. Virtual Pro. 8: 4-57.

Haller, H. L., L. D. Goodhue and H. A. Jones. 1942. The Constituents of derris and other rotenone-bearing plants. Chem. Rev. 30(1): 33-48.

Kannan, R. R. R., R. Arumugam and P. Anantharaman. 2010. In vitro antioxidant activities of ethanol extract from Enhalus acoroides (L.F.) Royle. Asian Pac. J. Trop. Med. 3(11): 898-901.

Khanam, Z., K. H. Sam, N. H. B. M. Zakaria, C. H. Ching and I. U. H. Bhat. 2015. Determination of polyphenolic content, HPLC analyses and DNA cleavage activity of Malaysian Averrhoa carambola L. fruit extracts. J. King Saud Univ. Sci. 27(4): 331-337.

Kuskoski, E. M., A. G. Asuero, A. M. Roncoso, J. Mancini-Filho and R. Fett. 2005. Aplicación de diversos métodos químicos para determinar actividad antioxidante en pulpa de frutos. Ciên. Tecnol. Aliment. 25(4): 726-732.

Li, N., K. Ragheb, G. Lawler, J. Sturgis, B. Rajwa, J. A. Melendez and J. P. Robinson. 2003. Mitochondrial complex I inhibitor rotenone induces apoptosis through enhancing mitochondrial reactive oxygen species production. J. Biol. Chem. 278(10): 8516-8525.

Lopera, Y. E., J. Fantinelli, L. F. Gonzalez Arbelaez, B. Rojano, J. L. Rios, G. Schinella and S. Mosca. 2013. Antioxidant activity and cardioprotective effect of a nonalcoholic extract of vaccinium meridionale swartz during ischemia-reperfusion in rats. Evid Based Compl. Altern. Med. 2013: 516727.

Maldonado-Celis, M. E., S. S. Arango-Varela and B. A. Rojano. 2014. Free radical scavenging capacity and cytotoxic and antiproliferative effects of Vaccinium meridionale Sw. agains colon cancer cell lines. Rev. Cubana Plant Med. 19(2): 172-184.

Martínez-Flórez, S., J. González-Gallego, J. M. Culebras and M. J. Tuñón. 2002. Los flavonoides: Propiedades y acciones antioxidantes. Nutr. Hosp. 26(6): 271-278.

Matsuda, H., K. Yoshida, K. Miyagawa, Y. Asao, S. Takayama, S. Nakashima, F. Xu and M. Yoshikawa. 2007. Rotenoids and flavonoids with anti-invasion of HT1080, anti-proliferation of U937, and differentiation-inducing activity in HL-60 from Erycibe expansa. Bioorg. Med. Chem. 15(3): 1539-1546.

Matsuda, H., K. Yoshida, K. Miyagawa, Y. Nemoto, Y. Asao and M. Yoshikawa. 2006. Nuphar alkaloids with immediately apoptosis-inducing activity from Nuphar pumilum and their structural requirements for the activity. Bioorg. Med. Chem. Lett. 16(6): 1567-1573.

Mosmann, T. 1983. Rapid colorimetric assay for cellular growth and survival: Application to proliferation and cytotoxicity assays. J. Immunol. Methods. 65(1): 55-63.

Osorio, C., B. Acevedo, S. Hillebrand, J. Carriazo, P. Winterhalter and A. L. Morales. 2010. Microencapsulation by spray-drying of anthocyanin pigments from Corozo (Bactris guineensis) fruit. J. Agric. Food Chem. 58(11): 6977-6985.

Paladino, S. C. 2008. Actividad antioxidante de los compuestos fenólicos contenidos en las semillas de la vid (Vitis vinifera L.) [MSc Dissertation]. Mendoza, Argentina: Universidad Nacional de Cuyo.

Raaman, N. 2006. Phytochemical Techniques, New India Publishing, New Delhi, p. 318.

Rasheed, S., W. A. Nelson-Rees, E. M. Toth, P. Arnstein and M. B. Gardner. 1974. Characterization of a newly derived human 
sarcoma cell line (HT-1080). Cancer. 33(4): 1027-1033.

Re, R., N. Pellegrini, A. Proteggente, A. Pannala, M. Yang and C. Rice-Evans. 1999. Antioxidant activity applying an improved ABTS radical cation decolorization assay. Free Radic. Biol. Med. 26(9-10): 1231-1237.

Rodríguez-Perón, J. M., J. R. Menéndez-López and Y. Trujillo-López. 2001. Radicales libres en la biomedicina y estrés oxidativo. Rev. Cubana Med. Milit. 30(1): 33-44.

Rojano, B., I. C. Zapata and F. B. Cortes. 2012. Estabilidad de antocianinas y valores de capacidad de absorbancia de radicales oxígeno (ORAC) de extractos acuosos de corozo (Bactris guineensis). Rev. Cubana Plant Med. 17(3): 244-255.

Seifried, H. E., D. E. Anderson, E. I. Fisher and J. A. Milner. 2007. A review of the interaction among dietary antioxidants and reactive oxygen species. J. Nutr. Biochem. 18(9): 567-579.

Sequeda-Castañeda, L. G. 2008. Capacidad antioxidante de extractos totales y fracciones de la especie vegetal Anacardium excelsum por métodos espectrofotométricos y composición de la fracción activa por CG-EM. [MSc Dissertation]. Bogotá. Colombia: Pontificia Universidad Javeriana.

Siegel, R., J. Ma, Z. Zou and A. Jemal. 2014. Cancer statistics, 2014. CA. Cancer J. Clin. 64(1): 9-29.

Singleton, V. L., R. Orthofer and R. M. Lamuela-Raventós. 1999. [14] Analysis of total phenols and other oxidation substrates and antioxidants by means of folin-ciocalteu reagent. Methods in Enzymology, Vol. 299. Academic Press, New York, Pp. 152-178.

Sonoda, M., T. Nishiyama, Y. Matsukawa and M. Moriyasu. 2004. Cytotoxic activities of flavonoids from two Scutellaria plants in Chinese medicine. J. Ethnopharmacol. 91(1): 65-68.

Sutachan, J. J., Z. Casas, S. L. Albarracin, B. R. Stab, $2^{\text {nd }}$, I. Samudio,
J. Gonzalez, L. Morales and G. E. Barreto. 2012. Cellular and molecular mechanisms of antioxidants in Parkinson's disease. Nutr. Neurosci. 15(3): 120-126.

Toaldo, I. M., F. A. Cruz, L. Alves Tde, J. S. De Gois, D. L. Borges, H. P. Cunha, E. L. da Silva and M. T. Bordignon-Luiz. 2015. Bioactive potential of Vitis labrusca L. grape juices from the Southern Region of Brazil: Phenolic and elemental composition and effect on lipid peroxidation in healthy subjects. Food Chem. 173: 527-535.

Tobar-Reyes, J. R., O. Franco-Mora, E. J. Morales-Rosales and J. G. Cruz-Castillo. 2009. Resveratrol content in leaves of Mexican wild grapevines (Vitis spp.). Rev. Fac. Cien. Agrar. UNCuyo. 41(2): 127-137.

Tyrakowska, B., A. Soffers, H. Szymusiak, S. Boeren, M. Boersma, K. Lemańska, J. Vervoort and I. M. Rietjens. 1999. TEAC antioxidant activity of 4-hydroxybenzoates. Free Radic. Biol. Med. 27(11-12): 1427-1436.

Valko, M., D. Leibfritz, J. Moncol, M. T. Cronin, M. Mazur and J. Telser. 2007. Free radicals and antioxidants in normal physiological functions and human disease. Int. J. Biochem. Cell. Biol. 39(1): 44-84.

Williams, R. J., J. P. Spencer and C. Rice-Evans. 2004. Flavonoids: Antioxidants or signalling molecules? Free Radic. Biol. Med. 36(7): 838-849.

Yan, S. W., R. Ramasamy, N. B. M. Alitheen and A. Rahmat. 2013. A comparative assessment of nutritional composition, total phenolic, total flavonoid, antioxidant capacity, and antioxidant vitamins of two types of Malaysian underutilized fruits (Averrhoa Bilimbiand Averrhoa Carambola). Int. J. Food Prop. 16(6): 1231-1244. 